\title{
Income Risk Perception and Management by Rural Farm Households, Taking Part in Sugarcane Contract Farming in Lao PDR
}

\author{
Saichay Phoumanivong ${ }^{1}$, Dusadee Ayuwat ${ }^{2} \&$ Chaicharn Wongsamun ${ }^{3}$ \\ ${ }^{1}$ Development Science Program, Faculty of Humanities and Social Sciences, Khon Kaen University (KKU), \\ Thailand \\ ${ }^{2}$ Department of Sociology and Anthropology, Faculty of Humanities and Social Sciences, KKU, Thailand \\ ${ }^{3}$ Department of Agricultural Extension, Faculty of Agriculture, KKU, Thailand \\ Correspondence: Dusadee Ayuwat, Faculty of Humanities and Social Sciences, Khon Kaen University,123 Moo \\ 16 Mittapap Road, Nai Muang, Muang District, Khon Kaen 40002, Thailand. Email: dusayu@kku.ac.th
}

$\begin{array}{lc}\text { Received: July 6, } 2015 & \text { Accepted: August 5, } 2015 \quad \text { Online Published: September 13, } 2015 \\ \text { doi:10.5539/jsd.v8n8p18 } & \text { URL: http://dx.doi.org/10.5539/jsd.v8n8p18 }\end{array}$

\begin{abstract}
This research aimed to examine income risk perception and management of sugarcane contract farming at farm household level in Lao PDR. The study was conducted using a qualitative approach, employing purposive sampling with a total target group of thirty respondents that included older people from the village and heads of the sugarcane grower group as the key informants. The target group also included twenty five farm households who were planting and harvesting at least one hectare of contract farming sugarcane during a single season in 2014. In-depth interviews, group interviews and observation techniques were employed. Data collection was done during October-December, 2014. Content analysis was employed for the data analysis while descriptive analytic methods were used to present the results. The results indicated the sources of income risk to rural farm households engaging in sugarcane contract farming. These risks included the high cost of clearing land; in particular land containing large trees, the high cost of sugarcane stalk, which was often supplied contaminated with soil and tree branches, the high cost of fertilizer and also labor costs caused by annual inflation. Households were aware of the income risks from sugarcane contract farming and used their own strategies to manage them. These strategies would include reducing the amount of inputs, using their own labor, renting out their land to others and diversification in to other crops and livestock.
\end{abstract}

Keywords: income risk, Lao PDR, risk management, rural farm household, sugarcane contract farming

\section{Introduction}

Agriculture plays an important role within developing countries, including Laos, where the agriculture sector provided 28\% of GDP in 2012 (World Bank, 2014) however, it is the case that the majority of the population relies upon agriculture for its subsistence. This majority is comprised of small farm households and those who live in rural areas. For many years, these households have been facing problems regarding low yields, the use of dated, conventional farming techniques, a lack of capital for purchasing inputs and an inability to access markets. Consequently, Laotian agriculture offers only a small proportion of its produce to the market and is mainly used for home consumption, leading to low household incomes.

Contract Farming (CF) in Lao PDR has been developed widely since 2002 (Fullbrook, 2007). CF offers an alternative approach to solving the problems faced by farm households and also provides a secure purchaser for their production. At the same time, the expansion of markets, particularly from cross-border investment and the promotion of agricultural products for sale through markets have been helpful. Contract farming is beneficial for both the households and the buyers. Households receive the necessary inputs for their farm, have a guaranteed market and receive advice on necessary farming techniques, while the buyers benefit from assured production from the $\mathrm{CF}$.

Since the Mitr Lao Sugar Factory was established in 2007, sugarcane contract farming has provided an alternative approach for farm households to raise their income, diverse from rice production. Consequently, sugarcane has been promoted as a means of raising the income of rural farm households in the area. 'Sugarcane is a crop that requires high investment for inputs, the households rely mainly on the factory for these inputs and 
it requires very close farm management as it is a costly business' (Waswa, Netondo, Maina, Naisiko \& Wanamati, 2009). Risk arises from the farm households not being used to sugarcane farming techniques and there being only one buyer in the area.

Khamsong Village, a fictitious name, Xaiburi District, Savannakhet Province, Lao PDR was selected as the study site as the households there have participated in sugarcane contract farming since 2008. It comprises of a group of forty five rural farm households planting sugarcane for contract farming. It contains a larger group than other nearby villages who also currently participate in CF. It is interesting to discover how rural farm households, who continue planting sugarcane, perceive their risk, particularity income risk, how they manage their risk and what are their strategies to cope with that risk.

Therefore, the focus of this study will be on the small farm households that are still participating in sugarcane contract farming in Khamsong Village. It will attempt to understand their sources of risk, their risk perception and their risk management, especially regarding income risk that may be useful for other farm households, who are participating in sugarcane contract farming, to develop risk management strategies and to develop their income levels in the future. The result of this study may be useful in designing an appropriate policy to improve the incomes of farm households who are facing these risks. The research objective is to examine income risk management, in sugarcane contract farming, for rural farm households.

\section{Methodological Framework}

\subsection{Concept and Research Framework}

Risk management is classified in differing ways by various authors. However, there are some common ideas regarding risk management. 'Risk management is the systematic application of management policies, procedures and practices to the tasks of identifying, analyzing, assessing, treating and monitoring risk' (Hardaker, Huirne, Anderson, \& Lien, 2004). 'It may help to identify key competency areas in which an organization could improve its ability to manage risk' (Reuvid, 2009). 'It is a process that identifies loss exposure faced by an organization and selects the most appropriate techniques for treating' (Rejda, 2008).

In this study, risk management was applied to identify risks encountered by rural farm households in sugarcane contract farming, to explore how they manage their risk and how they respond to that risk.

\subsection{Research Methodology}

A qualitative approach was employed in this study to explore the in-depth situation of income risk faced by rural farm households and their risk management within sugarcane contract farming. Khamsong Village was selected as the study site. The Khamsong sugarcane growers group was one of twenty eight sugarcane grower groups in Xaiburi district. It was larger than other nearby groups, both in terms of its land growing area, and the number of households participating in sugarcane contract farming.

There were a total of thirty respondents interviewed in this study, comprising of five key informants (older people from the village and heads of the sugarcane grower group) and twenty five heads of farm households who were participating in sugarcane contract farming, or who were the household members who led the sugarcane contract farming. Households were selected for interview based on having at least one hectare of sugarcane land harvested during the cane season of 2014 and who were members of the Khamsong grower group.

In order to gain an in depth understanding, the researchers divided the interviews in to village level and household level. The researchers started their work by going to the area of study and observing, later they group interviewed older people in the village and also the heads of the sugarcane grower group to understand the socio-economic context and gain an overview of sugarcane contract farming in Khamsong Village. Finally the rural farm households were interviewed, in depth, in order to understand their risks and the management of income risk within their farm households.

In-depth interview and group interview (Creswell, 2012) was combined with two sets of semi-structured guidelines, one set for in-depth interview at village level and another set for interview at household level. Observation techniques were also added in to this study for triangulation and to obtain enriched data.

Content analysis was employed, combined with triangulation to enhance the accuracy of the data (Creswell, 2008).

\section{Results and Discussion}

- The findings of this study lead to an understanding of the households' income risks and their risk management strategies, the results are presented as follows:

- Context of the Village 
- Perception of Income Risk

- Risk Management in Sugarcane Contract Farming by Rural Farm Households

\subsection{Context of the Village}

Khamsong Village, Xaibury District, Savannakhet Province, Lao PDR is located on high ground, about 6.8 Kilometres $(\mathrm{km})$ away from the Mitr Lao Sugar Factory to the east, and Road Number 13 (South) which connects further to Vientiane, the capital of Lao PDR or to the southern part of Lao PDR. It is $14 \mathrm{~km}$ away from the Xaiburi District Office to the north and, it is $76 \mathrm{~km}$ away from Kaisorn Phomvihan District, the capital District of Savannakhet. Consequently, there were no problems for farm households in travelling or connecting with outsiders by road and by telephone.

In 2008, a project was introduced to aid future development, three small villages (Khamsong, Kaeng (factitious name) and Hui (factitious name) were gathered together to form one big village under the name "Khamsong". This name was selected from the three, based on it having the largest area and population and with the agreement of the members of all three villages. Khamsong is a Lao Loum ethnic Village. Based on data from the village head, there are 220 households in the village, with a total population of 957 people, comprising 372 males and 585 females.

The land area of the village is, in total, about 2,000 hectare (ha), including; 323.9 ha of sugarcane fields, owned by 63 households in the village, 257 ha of rice fields owned by 101 households, 7 ha of village forest conservation area, 6 ha of graveyard as well as several hectare of sugarcane fields owned by the Mitr Lao sugar factory on concession land from the government. There are also several hectares of sugarcane field owned by local and foreign businessmen. It was not clear what some areas of land was used for due to it being quite a large village and the length of time needed to check exact land use.

The main income source for the majority of the villagers was rice. However, households could grow only rain-fed rice, due to there being no public irrigation system in Khamsong village and it being located on high ground. The average rice yield was 2-3 ton per hectare, compared to other areas (3.5-4 ton/ha). The yield was quite low for the area. However, each household had a number of rice fields providing sufficient rice for household use with some surplus for sale. There were ten households in the village that were selling rice every year, while others would sell rice only occasionally.

Additional income sources, besides rice were livestock, rubber, pineapple and banana. Because of low income from rice, householders would try to find alternative sources to raise the income of their household. There were ten households in the village planting rubber, six households planting pineapple or banana, more than half of all households raised a cow, and two households raised goats. To enhance their income from the agricultural sector, some householders, when they had free time from their farming, decided to find work in other provinces, while some went to Thailand to work in factories in Bangkok or to work on rubber farms in the south of Thailand.

The Mitr Lao Sugar Factory was established in Xaiburi District in 2007 and, consequently sugarcane contract farming became another new source of income for the farm households. At first, there were five households in the village who participated in sugarcane contract farming, all were successful in raising their income and this became a good example for the other households to follow. Later, more households became interested in sugarcane contract farming with the hope that they too could make a bigger income.

\subsection{Perception of Income Risk}

To understand the perception of income risk to rural farm households, it is necessary to explore the risk through the practices of sugarcane contract farming, and these are presented as follows: Preparing for the Sugarcane Contract Farming with the Factory, Clearing Land, Planting Sugarcane, Applying Fertilizer, Controlling Weeds, Cutting and Transporting the Sugarcane to the Factory.

Preparing for the Sugarcane Contract Farming with the Factory:

After the establishment of the Mitr Lao Sugar factory, sugarcane CF became an important alternative and popular source of income for farm households. More and more farm households wanted to participate in this type of farming because they believed that it involved a low investment from them while the factory provided most of the necessary inputs for planting the sugarcane, the households were required to invest only their own labor and land. Some households considered that they did not make any investment, as Mr. Ya (fictitious name) mentioned "we did not invest at all, all inputs were provided by the factory"

There were no complicated steps to participating in CF; first, farm households informed the factory's staff of their desire to join in sugarcane contract farming, later, if the household passed the factory's criteria that mainly 
concerned land and labor, then a contract between the factory and the household was made. The factory would then support them by supplying the necessary inputs to the farm household and also provide advice on planting techniques.

There were four types of farm household sugarcane field in the village. The first type was households who used their vacant land to convert to sugarcane, second were households who used their vacant land and rice fields as sugarcane fields, third were households who used some of their rice fields for sugarcane and fourth were households who used all of their rice fields for sugarcane. Sugarcane may be considered a big money earner but most households would still want to keep some of their land for planting rice for their home consumption. Households still believe that rice is important; it ensures food for their own consumption and, even if low profit, still retains the good points of providing a stable income, low investment costs, low risk and households rarely lose from rice plantation.

Before planting sugarcane for $\mathrm{CF}$, households would contact the factory by going directly to the factory or meeting with the field head or 'Nai Paeng' (local name). Then the factory staff would visit the land with some of the criteria for planting sugarcane such as the land and labor required for planting sugarcane. A few days later, if the household fulfilled the criteria, the factory and the household would make a contract to plant sugarcane. Later, the factory would provide the households with some necessary inputs for planting sugarcane, staring with clearing the land, through to harvesting and transporting the mature sugarcane to the factory. The factory provided land clearing, sugarcane stalks, fertilizer, herbicide to control the weeds and advice on planting techniques. Usually the new households made a contract with the factory before the sugarcane planting season. The contract might be made in writing or be a verbal contract, but the household understood clearly that they had to plant sugarcane for the factory, they could not sell to others and that the factory would support inputs. The household would receive inputs supported by the factory and they could also invest themselves, if they had sufficient money.

Based on an interview with a sugarcane group member, the factory divided the sugarcane fields in Xaiburi District into thirty five zones comprising of sugarcane fields owned by the factory, fields owned by local and foreign businessmen, and the contract sugarcane fields owned by farm households. In every zone, the factory appointed their staff to work with the farm households in support of the sugarcane plantation, mainly a field head and a head of zone. The field head was a factory staff member who worked closely with the households, while the zone head was also a factory staff member who was senior to the field head. Farm households would contact the field head mainly by phone, or would go to his office when they needed some help such as with clearing land, sugarcane stalks, fertilizer or herbicide. The farm households avoided direct contact with the zone head as the field head was responsible directly to the farm households.

\section{Clearing Land:}

The factory's staff advised that during the planting season, land should be ploughed 3-4 times depending on the conditions. If the vacant land had no large trees, it may not need to be ploughed so many times, which made the cost of clearing the land cheaper. The land should be ploughed over two periods. First, it should be ploughed one or two times and then left to let the soil dry for a few weeks in order to let the weeds and insects be killed by the sun light, and to make the soil ready to absorb water. In the second period, the land should be ploughed one or two more times to make the soil ready for planting. Initially, the cost of clearing land (with large trees) was 17,000 Baht /ha (US\$ 531.31), (1 US\$=32 Baht), unfortunately, it had reached (US\$ 1,188) per ha by 2013. Fortunately, in 2014 there were some heavy machines from the north of Lao PDR that came to the area and offered to clear land at a price of US\$156- US\$313 /ha. At first, the cost of clearing land was rather high, but regardless, households still wanted their land cleared. Though they could not pay for it by themselves, it was a good chance for them to have the factory clear the land, even at the risk of debt, as they thought that they could at least clear their land and it would be ready for plantation, in the future, even if they stopped planting sugarcane. Consequently, there was a high cost for the farm households to extend their sugarcane fields and there was a potential risk from being in debt.

In practice, during the planting season, some households could not follow this step as the heavy machinery was in high demand at the time, so it was not always easy for the farm households to follow the advice of the factory. Consequently, some households were ploughing insufficiently before planting. Other households were late ploughing and planting. Some households had ploughed only part of their land and then stopped, meaning they must wait until the next year to plough and plant completely.

Those households who failed to plough sufficiently found they had lots of weeds in their field, as the ploughing was not sufficient to control the weeds in the soil. Regarding the households who were late ploughing and 
planting, growing sugarcane relies heavily on rain water, late planting meant that the rainy season was gone, there was no rain or water for the sugarcane, leading to low sprouting, low yields, low profit and a high risk of loss from the investment. For households who had ploughed only part of their land and then stopped, it meant that they would have to wait until the next year to plough and plant. This situation caused the households to accumulate costs and additional interest while they had to start the ploughing process again the following year. To save costs, some households decided to convert their rice fields to sugarcane as this helped the farm household greatly and offered more chance of making a profit from their investment because they had spent little money on clearing land.

The high cost of clearing land was one main source of high input costs for farm households, differing land conditions would result in varying costs of land clearance.

\section{Planting Sugarcane:}

Almost all of the households used large tractors (with planting machines installed). These tractors were provided by the factory for the sugarcane planting because the area was too large for manual labor and in order to preserve the quality of the sugarcane stalk seed, stalk quality would be degraded if kept unplanted for several days. At planting time there was high demand for the tractors, some households who had smaller planting areas (2-3 ha) decided to plant sugarcane using their own labor, or paid laborers, so that they would not miss the planting season and also to preserve the quality of their sugarcane stalk.

Selecting the sugarcane stalks was also important at this point, because if the stalks were low quality then there was a reduced chance of growth. A good sugarcane stalk should be new or replanted immediately, within a few days of cutting. It was also important to keep the stalk from becoming too dry as it needed to be stored in a humid place and not in direct sunlight. Usually the stalk would come from Thailand, such as from Khon Kaen Province. Many households said that they received low quality stalk which meant a low chance of growth.

Initially, the sugarcane stalk cost was 1 to 1.5 , meaning that if households took credit for 1 ton of stalk, next season, when they harvested their sugarcane, they would pay back to the factory 1.5 tons of cane. Since 2013, the stalk cost has been reduced to 1:1 which should bring about savings for the farm households. Some farm households decided to use their own sugarcane or exchanged with their relatives and friends in order to replant again in the next season. This was in order to save on costs and have the ability to select and keep the stalks for themselves. Some said that their stalks were in better condition, with better growth and higher yield, while others said that the stalk from the factory was better because it carried no diseases.

Sugarcane stalk was another source of high input costs. For instance, when staff transferred 10 tons of stalks, only 7-8 tons could be used, the rest was soil and tree branches that came mixed-in with the sugarcane stalks. But households still had to pay for 10 tons of stalk instead of the 7-8 tons that were usable (table 1).

\section{Applied Fertilizer:}

Households were advised to apply fertilizer three times, first during planting, secondly after killing the weeds or when the sugarcane was observed to be about 50 centimeters tall and the third time when the sugarcane was about 2 meters tall. They used 18 bags of fertilizer per hectare, 1 bag weighed $50 \mathrm{Kg}$, originally it cost US\$28, at present it is US\$ 31 - US $\$ 38 /$ bag. This fertilizer was provided by the factory, on credit.

In practice, and to save cost, almost all households applied fertilizer only twice (in total $12 \mathrm{bags} / \mathrm{ha}$ ) as they believed that their soil was fertile enough and did not need so much chemical fertilizer. They kept some fertilizer from the factory for use on their rice fields in order to save on cost and extend other investments. In reality, this may have affected the sugarcane yield as they did not follow the planting techniques as provided by the factory.

If the households paid for a worker to apply the fertilizer for them, the householders had to check whether or not it was applied correctly because this may affect their input costs and the yield from the sugarcane. If they were careless at this stage, it meant that the households could be wasting their money, with the prospect of no return as applying of fertilizer improperly would result in a possible zero return.

The price of fertilizer increases annually, and the amount of fertilizer required trends to increase also, therefore, fertilizer is one source of high input cost that may lead to income risk for the farm households

Controlling Weeds:

It was advised that the first control of the weeds should take place during a 1-2 week period immediately after planting the sugarcane, in order to control the weeds before they could get established. The second control was due when the sugarcane had reached $50 \mathrm{~cm}$ or if it could be observed that the weeds had started to cover the ground. Some households administered the chemical themselves to save on cost, while others decided to pay 
workers to undertake this step for them because of concerns over health risks. Therefore, there would often be two costs related to the spraying: paying for the weed killing liquid at US\$38 and payment for the workers to apply it at US\$16, both of which were met by credit from the factory. The workers who did this job often came from the many nearby villages and as they did not own sugarcane or rice fields of their own, this was a way to earn a living.

Some households had a problem with the smell of the chemical so they tried to keep as far away as they could by paying a worker to spray the sugarcane field and neglected to check the application. Later, problems arose because some workers were careless when spraying or sprayed only a part of the field which damaged the soil and impacted on the river and rice fields near to the sugarcane field. However, there has been no evidence, as yet, to show that chemical spraying caused environmental problems in the area.

Some households, who sprayed by themselves, reported a few cases of effects from spaying the chemical, but these were not considered serious. The problems that did occur were caused by not properly using the protective equipment when spraying the chemical such as, not having enough protective equipment, having enough equipment but not being familiar with how to use it, or it was too hot and uncomfortable to wear the equipment in hot weather. In the cases where there were only low levels of weed at their farm, households decided to control it by human labor (by hand) rather than using chemical spraying.

Fortunately, some investigators from the Health Office of Savannakhet Province visited the village and as a result, from 2013, the factory provided herbicide that had a low effect upon people and the environment. The householders said that the chemical was safe enough that they could even eat while spraying, without having any effect on their health, while the spray still retained a high level of weed control.

Cutting and Transporting the Sugarcane to the Factory:

When cutting sugarcane, households had to pay for laborers in their village, or from a nearby village, to cut and lift the sugarcane on to the truck. The cutting cost was US $\$ 0.03$ for 10-12 sugarcane stalks (one bunch) and lifting on to the truck cost US $\$ 2.5 /$ ton. In the case of an emergency or a lack of labor, the rate may be higher. To find the labor for this process, households used strategies such as making a prior agreement with workers, providing a vehicle to pick them up and supplying a free lunch, while some households encouraged their laborers by making an advance payment when the laborer was in urgent need of money. Some of the households reciprocated, by assisting the laborers to plough their own rice fields during the rice planting season. As $\mathrm{Mr}$ Kham (fictitious name) said "I help them first, then they help me in return"

During the cutting or harvesting season, households were very busy and some householders had to leave home and stay many days at the farm while cutting the sugarcane or guarding the cane to make sure that there was no fire spread from other, nearby farms. Sometimes, they had to cut the sugarcane at night, using petrol powered lights, due to the lack of labor available during the day. During this time, the farm households were also busy with trying to find cutting laborers and often neglected their duties at home such as taking care of the children and taking them to school.

In the case where a sugarcane field was burned, there was little chance of making a profit from the investment, because the burned sugarcane had to be transferred to the factory as fast as possible in order to preserve its weight, and the cost of labor may be higher than normal. The longer the cane is kept, the lower the weight and the lower the price. The household had to urgently find labor for the cutting and lifting and so was faced with the problem of higher than normal labor costs. Consequently, the investment cost was raised with the prospect of low or no profits.

Burned sugarcane stalk was easy to cut. Therefore, some households preferred to burn their sugarcane rather than cut it fresh; this was because they had procured enough labor and had a truck waiting to transfer the sugarcane to the factory immediately after cutting. But if a household lost control of the fire and could not keep it from reaching a neighboring farm, there could be an accident. The neighbouring farm may experience losing their sugarcane to the fire and so having to cut it immediately.

Cutting the sugarcane and removing some of the leaves after cutting, affected the selling price of the sugarcane at the factory. There were three different prices: 1,100 Baht (US\$34.4) for fresh stalk sugarcane with leaves cleared, 1,050 Baht (US\$32.8) for fresh sugarcane with the leaves intact and 1,030 Baht (US\$32.2) for burned sugarcane stalk. The factory preferred the sugarcane with leaves already cleared and attracted the householders to supply in this way by offering the highest price however, the cutters did not prefer this method because it took more time.

The factory did not favor burned sugarcane as it provided a low level of sugar, but sometimes it was very 
difficult for the households to avoid this. The householders did not always decide to burn for themselves, but could be affected by flames spreading from a neighboring farm, which had intended to burn. Under these circumstances the affected households had to find cutting labor immediately because, if kept for a long time after burning, the result would be a low sugar level and a low price. Therefore, the demand for cutting labor at this time was very high, consequently, the high cost of cutting labor affected accumulating higher costs.

Regarding delivery to the factory, this was an important process, the faster the delivery, the higher the quality and weight of the sugarcane. Households had the choice of two types of transportation to the factory: to ask for the factory truck to collect or to provide their own truck. Some households had the idea of cutting the sugarcane using their own household labor and delivering it themselves, using their own small tractor to deliver 3-5 tons per time, making two deliveries per day. By using this method they could deliver immediately after cutting. However, a few of the larger farm households were unable to operate in this way and they had to wait. Unfortunately a few households were not able to deliver to the factory during the 2010 season, therefore, all the harvested sugarcane became waste and they lost money.

Cutting and lifting the sugarcane on to the truck takes place during the peak labor season. As labor is in great demand at that time, the households have to pay higher than normal rates, making the cost of production high.

Regarding the process of sugarcane contract farming, it could be concluded that the perception of income risk faced by rural farm households would include, the high costs of clearing land, high cost of sugarcane stalk, high cost of fertilizer and the high cost of labor.

\subsection{Risk Management in Sugarcane Contract Farming by Rural Farm Households}

Households who participate in sugarcane contract farming may face income risk. However, some strategies to reduce their income risk are as follows:

\subsubsection{Reduced Amount of Input or Replacement by Local Inputs}

Planting sugarcane needs important inputs such as fertilizer, sugarcane stalk, and herbicides which are produced outside the farm. Consequently, the high level of inputs bring with them high production costs, therefore, households tried to minimize these costs by trying to reduce some inputs and/or replace them with produce from their own farm or from a village nearby. These inputs were fertilizer and sugarcane stalk.

Fertilizer was one area of possible cost reduction. It was suggested by the factory staff that the fertilizer should be applied three times (totally $18 \mathrm{bags} / \mathrm{ha}$ ). But, in order to reduce costs, households applied only twice (totally $12 \mathrm{bag} / \mathrm{ha}$ ). Some households decided to reduce fertilizer and use additional manure from their farms (table 1). Some households thought that their soil was fertile enough and after they reduced the amount of fertilizer their yields remained the same. Consequently, these households found that even when they reduced the amount of fertilizer, the yield still remained the same, so their costs were reduced. Unfortunately, other households, whose sugarcane fields were not as fertile, found that their yields were lower when they reduced the amount of fertilizer.

Sugarcane Stalk was another area in which costs could be reduced by exchanging stalks for replanting with friends or neighbors instead of getting them from the factory directly (replaced by local inputs) (table 1), however, these sugarcane stalks faced problems from disease.

In a related study, it was found that using local inputs also helped to reduce production costs and raised the positive impact on the income from tea production in Vietnam (Saigenju \& Zekker, 2009). Reduced input costs may reduce income risk for farm households but, it should be made clear that the input quality must be very similar in order to avoid low yields.

Reducing amounts of input or replacing them with local inputs are risk management options for farm households, in order to reduce their income risk.

\subsubsection{Using Household Labor}

Using household labor was one way of reducing costs. The households used their own labor when they had time or when the work did not have to be done in a hurry, such as when replanting for the second time, spraying herbicide or controlling weeds. However, larger areas of sugarcane may not be suitable for household labor and the farmers would need to hire labor and use heavy machines instead.

In spraying herbicide, some households paid workers to spray for them at US\$16/bottle. Other households sprayed the herbicide themselves, in order to save paying for laborers, when spraying they protected themselves by wearing masks, boots and long, thick clothes. To date, no households have reported a serious case, nor has anyone died, from the effects of spraying herbicide in the village. 
Using household labor is one option for risk management that is available to the farm households in order to reduce income risk.

\subsubsection{Renting Out Their Land to Others}

Many households, who had experienced planting more than 10 hectares, got into debt, consequently, they decided to reduce their sugarcane fields to 2-3 hectares, and rented out the rest of their land to the factory or to other business men.

Sugarcane requires being looked after closely at almost every stage. Starting from land preparation, replanting, weed control, harvesting and transfer to the factory. Households reported that if they planted sugarcane on 2-3 hectares they could make a profit, as they were able to look after their crop closely, but if the sugarcane field was larger than that, they risked getting into debt as a result of a lack of time and labor spent on the crop.

The rent money, received for their land, was used to cut household debt from the previous season (fertilizer, sugarcane stalk, herbicide, land preparation). Some land had to be rented to the sugar company for 10 years or more, in order to compensate for their debt. Previously the rental price was US $\$ 10$ per hectare per year, at present, the rental rate has been raised to US $\$ 312$ rai/year ( 1 hectare $(\mathrm{ha})=6.25$ rai). This minimizing of their land size was similar to the findings of a study from Minot and Ngigi (2004), who studied contract farming in Kenya where farm households shifted from large-scale to small-scale production when they had tasted failure.

\subsubsection{Diversification in to Other Crops and Livestock}

Besides sugarcane and rice, households still looked for other crops to ensure their household income. The households diversified in to other crops including Rubber, Banana and Pineapple.

Rubber, banana and bineapple fields were considered as insurance for their income. Households that could access inputs for themselves divided their land for planting of other crops such as rubber, banana and pineapple, in order to provide diverse sources of income alongside rice and sugarcane. This household strategy was to ensure against one product having a low price or loss while giving the hope of a profit from another crop.

Rubber planation required the households to invest their own money as there was no company to support the rubber growers, while sugarcane contract farming was supported by the Mitr Lao sugar factory that provided, in advance, the necessary inputs on credit. Even thought the factory charged 6.5 percent per year for the advance credit, it was acceptable to the households. There were twenty eight households in the villages planting rubber on 94 ha. Five out of the twenty eight households were planting both rubber and sugarcane. It was suggested that rubber could also earn good income for a household, therefore, additionally, about four households, who were planting sugarcane, started to plant rubber in 2014. Households invested their own money, US\$ 0.8 /baby rubber tree with 500 baby rubber trees per hectare meaning that households had to invest at least US\$391/ha in rubber. The household would have to take care of the plants for 4-6 years before harvesting the first yield. Rubber was a good price, US\$3/kilo, while banana and pineapple occupied only a small market.

Rubber plantation was best suited to households who had their own money for investment or who were 'better off' as there was no company to support inputs or credit. Conversely, in sugarcane contract farming, the Mitr Lao Company supported households with inputs including credit so consequently even poor households could participate in sugarcane farming, if they had the land and labor suitable for sugarcane CF.

In many cases, the rice produced was mainly for home consumption with the surplus offered for sale. However, in this area, a few households were planting rice for sale to ensure household income other than from sugarcane. The households believed that rice provided a low income but was also a low investment. In some parts of the village, near to the stream, rice provided a good yield (3.5-4 Ton/hectare), because of plentiful water and good soil fertility therefore, households did not need to apply chemical fertilizer so their investment costs were low. Households could earn less money than from sugarcane but with lower costs. In this study area, rice was not only for ensuring food for the farm household but also to provide a secure source of income as well.

Similar to a study by Kimura, Anton \& Lethi (2010) conducted in six countries (Australia, Estonia, Germany, Italy, The Netherlands and UK) it was found that crop diversification was one important strategy to reduce income risk at farm household level.

Livestock:

Cows were another source of income for the households in addition to sugarcane. Some households accrued debts for many years, so they decided to turn their sugarcane fields in to cow fields instead. The cows could also bring a good price, US\$250-US\$938 based on their size, along with low input costs. Additionally, their land (formerly a sugarcane field) was ready to become a cow field as it was already bordered by fencing. Beyond the 
good price, cow dung was beneficial to the rice fields as it provided a natural fertilizer, instead of buying chemical fertilizer, and it was a free input for their farm, reducing production costs.

Goats were raised in only a few households because it was difficult to find a goat breeder locally, while cows were raised, over many years, in almost all households, so they had their own breeding stock without having to buy. Goats could sell for US\$47-US\$63 based on the size of the goat.

Diversification in to other products is one method of risk management, available to the farm households, in order to reduce their income risk.

Table1. Summary of the income risk management by rural farm household

\begin{tabular}{ll}
\hline \multicolumn{1}{c}{ Sources of Income Risk } & \multicolumn{1}{c}{ Risk Management } \\
\hline Mixed with soil and tree branches & Exchange or buy from friend or neighbor nearby to save stalk cost \\
high cost of fertilizer & Reduce from 18 to 12 bags and use farm manure \\
high cost of labor & Use own labor \\
high cost of clearing land & Convert rice field to sugarcane field \\
Failed sugarcane farm management & -Rent out some land to the factory or to others \\
Fluctuating yield & - Diversify into other crops \\
\hline
\end{tabular}

\section{Conclusion and Recommendation}

From this qualitative study it was found that the rural farm households perceived a number of sources of income risk, including the high cost of clearing land, particularly land with large trees, the high cost of sugarcane stalk because it was supplied mixed with soil and tree branches, the high cost of fertilizer and the high cost of labor caused by prices rising every year. Consequently, they managed their risk by reducing the amount of inputs or replaced them with local inputs such as; fertilizer, they used their own labor instead of hiring, they rented out their land to others in order to reduce their farm size while they diversified in to other crops and raised livestock to ensure their households' income. Households perceived the risks involved in sugarcane contract farming; but still participated and found their own ways of managing the risks they were facing.

From this study, the researchers would like to propose that: for effective risk management by farm households, it is necessary for the farm households to acquire more knowledge and experience of sugarcane plantation techniques and farm management. Contract farming requires the involvement of multiple parties, not only the farm households and the factory, the farm households seem to manage their risks by themselves. Some other organizations should be involved, such as development groups, the government sector or NGO's in order to facilitate helping the households to manage their risks, and to monitor the contract between the farm household and the factory, in order to control the quality of inputs and to make regulations to ensure that sugarcane contract farming will bring benefit and be sustainable at farm household level.

\section{Acknowledgements}

The authors wish to thank the Graduate School, Khon Kaen University, Thailand for support funding, as well as thanking all interviewees, particularly the sugarcane households in Khamsong Village who shared their real experience of sugarcane contract farming. Also, thanks for the Data from Xaiburi Agriculture for Promotion and the Forestry Office and for their organizing of some parts of the interview.

\section{References}

Creswell, J. W. (2008). Educational Research Planning, Conducting and Evaluating Quantitative and Qualitative Research. International Pearson Merril Prentice Hall.

Creswell, J. W. (2012). Qualitative Inquiry \& Research Design, Choosing Among Five Approaches. SAGE: Publications Ltd.

Fullbrook, D. (2007). Contract Farming in Lao PDR: Cases and Questions. The Laos Extension for Agriculture Project, Ministry of Agriculture and Forestry, Lao PDR. Retrieved January 4, 2015, from http://www.forestcarbonasia.org/wp-content/uploads/2012/06/Fullbrook-2011-Laos-Smallholder-production -agreements-qualifying-success.pdf

Hardaker, J. B., Huirne, R. B. M., Aderson, J. R., \& Lien, G. (2004). Coping with risk in agriculture. Oxford: 
CABI. http://dx.doi.org/10.1079/9780851998312.0000

Kara, E. K., \& Gebizlioglu, O. L. (2014). Measurement of bivariate risks by the north-south quantile points approach. Journal of Computational and Applied Mathematics, 255, 208-215. http://dx.doi.org/10.1016/j.cam.2013.04.050

Kumura, S., Anto, J., \& Le Thai, C. (2010). Farm level analysis of risk and risk management strategies and policies: cross country analysis. OECD food, agriculture and fisheries working paper NO.26. Retrieved January 3, 2015, from http://www.oecd-ilibrary.org/docserver/download/5kmd6b5rl5kd.pdf?expires=1440085638\&id=id\&accnam $\mathrm{e}=$ guest\&checksum=7C0C809CC49A34EDCF29BBDF34ED2AB8

Minot, N., \& Ngigi, M. (2004). Are horticultural exports a replicable success story? Evidence from Kenya and Co^te d'Ivoire. Environment production and technology division discussion paper no. 120 and MTID discussion paper no. 73. Washington, DC: International Food Policy Research Institute.

Rejda, G. E. (2008). Principles of Risk Management and Insurance. Boston: Greg Tobin.

Reuvid, J. (Ed.). (2009). Managing business risk: a practical guide to protecting your business. London.

Waswa, F., Netondo, G., Maina, L., Naisiko, T., \& Wanamati, J. (2009). Potential of Corporate Social Responsibility for Poverty Alleviation among Contract Sugarcane Farmers in the Nzoia Sugarbelt, Western Kenya. Agric Environment Ethics, 22, 463-475. http://dx.doi.org/10.1007/s10806-009-9165-6

World Bank. (2014). World Development Indicators: Structure of output. Retrieved January 3, 2015, from http://wdi.worldbank.org/table/4.2

\section{Copyrights}

Copyright for this article is retained by the author(s), with first publication rights granted to the journal.

This is an open-access article distributed under the terms and conditions of the Creative Commons Attribution license (http://creativecommons.org/licenses/by/3.0/). 